Website : http://ejournal.umm.ac.id/index.php/jpa | E-mail : jpa@umm.ac.id

Jurnal Perempuan dan Anak (JPA), Vol 3 No.2, Agustus 2020, pp. 65-73

ISSN: 2442-2614 print | 2716-3253 online

Universitas Muhammadiyah Malang

\title{
Life Skill For Women Empowerment: Patchwork For Creativity And Entrepreneurship
}

\author{
Laela Hikmah Nurbatra ${ }^{1 *}$, Hartono ${ }^{2}$ \\ a),b) Universitas Muhammadiyah Malang, Malang, Indonesia \\ *Corresponding Author \\ e-mail: nurbatra@gimail.com
}

\begin{abstract}
Abstrak
Pengabdian masyarakat ini merupakan program life skill pemberdayaan perempuan. secara khusus, program pemberdayaan masyarakat ini melibatkan anggota PKK RT 03 RW 02 Sumbersekar, Dau Malang. Saat ini terdapat 32 anggota PKK yang berasal dari latar belakang sosial ekonomi yang berbeda. Dalam hal keterampilan kewirausahaan, perempuan di wilayah tersebut memiliki pengetahuan dan keterampilan yang terbatas dalam berwirausaha. Berdasarkan observasi dan dikonfirmasi dengan hasil wawancara, sebagian besar perempuan yang menjadi anggota PKK RT 03 RW 02 merupakan keluarga kelas menengah ke bawah yang menggantungkan hidup pada penghasilan suami dari bertani. Mengingat sebagian besar anggotanya menggantungkan pendapatannya dari sektor pertanian, sebagian besar dari mereka tidak memiliki latar belakang pendidikan yang memadai. Meski masyarakat memiliki kendala dana yang terbatas untuk mendukung programnya, mereka memiliki kreativitas yang baik. Selain itu, mengingat Indeks Pemberdayaan Gender di Jawa Timur masih rendah, program pemberdayaan masyarakat kali ini bermaksud menawarkan solusi pemberdayaan perempuan di PKK RT 03 RW 02 Sumbersekar dengan harapan tidak hanya memberikan ruang lebih bagi kreativitas mereka. tetapi juga dukungan finansial mereka. Sejalan dengan itu, program pengabdian masyarakat saat ini tidak hanya bertujuan untuk memberdayakan perempuan, tetapi juga meningkatkan perekonomian mereka. Hasil dari program ini menunjukkan bahwa program berjalan dengan sukses meskipun dilakukan pada pandemi COVID 19. Beberapa penyesuaian telah dilakukan, namun tidak mengubah fakta bahwa masyarakat sasaran mendapatkan efek positif dari program pemberdayaan ini.
\end{abstract}

Kata kunci : Pemberdayaan Perempuan, Kemampuan, Kewirausahaan

\begin{abstract}
The present community service highlights life skill program for women empowerment. Particularly, the current community empowerment program involves members of PKK of RT 03 RW 02 Sumbersekar, Dau Malang. There are currently 32 members in the organization that comes from different socio-economic background. In terms of entrepreneurial skills, the women in the particular organization have limited knowledge and skill in entrepreneurship. Based on the observation and confirmed with the result of interview, most of the women who are the member of PKK $R T 03 R W 02$ are low-middle class family who rely on the husbands' income from farming. Given that most of the members relies on agricultural sector as their income, most of them do not have a sufficient educational background. Although the community has issue with limited fund to support their program, they have a good creativity. In addition, given that the Gender Empowerment Index in East Java is still low, the present community empowerment program intends to offer solution to empower the women at PKK RT 03 RW 02 Sumbersekar with the expectation that it will not only provide more space for their creativity but also their financial support. In accordance to that, the present community service program is not only aims to empower the women, but also improve their economics. The results indicated that the program ran successfully although it was conducted in the COVID 19 pandemic. Some adjustments have been made, but it did not change the fact the target communities obtained the positive effect from the empowerment program.
\end{abstract}

Keyword: women empowerment, life skills, entrepreneurship 


\section{Introduction}

Women play important part in the family. They are the ones who do not only manage the family, but also the one who are responsible in every aspect in the family members' life. This is including the economic status in the family, which is highly affected by the income of the family. In this regard, the statistic of BPS particularly 2018 Gender Empowerment Index in East Java provice is quite similar with DIY Yogyakarta, which reach the same level at 69,37. The level is far from the achievement of Central Java province which shows that the Gender Empowerment Index is 75.10. From the data, it can be inferred that women empowerment program needs to be conducted to address this issue.

Women are vulnerable not only because of their physical condition, but also because of their ecosocio status in the society. As most women are housewives, they are dependent to the husband and make them have less power compared to men. In this case, government has established particular organization which concern about the women's position within the society. Women across the nation are united in the organization called PKK or The Family Welfare Movement. It is regarded as women's organization which is supported by the government with aims to promote social welfare starting from family level (Adzmy \& Disyacitta, 2018).

Equally important, the present community empowerment program will emphasize on life skill, which is regarded as important skill to be mastered by individuals to survive in this era. It covers the necessary behavior which aims at preparing any individuals to deal with challenges in life which can be very complicated to cope (Masyhud et al., 2019). One of the life skills is entrepreneurship which also implies creativity, perseverance, problem solving, and time management.

Particularly, the current community empowerment program involve members of PKK of RT 03 RW 02 Sumbersekar, Dau Malang. There are currently 32 members in the organization that comes from different socio-economic background. Demographically, most of them do not have a formal job; they earn their living from agricultural sector since some of them are farmers, domestic helpers, or small scale-street vendors. There are three women who work as teachers as their occupation. Most of the family could not afford for the children's higher education, as they are mostly directed to go to the workforce upon their school graduation. Moreover, there are high numbers of school dropout level in the neighborhood which indicate the low level of educational awareness. There are also reports on early marriages of the youngsters in their teenage life due to unsafe sex. It is expected that by having the community empowerment program, the women in the target institution can improve their quality of living which also affect other members within the family. Based on the interview with the coordinator of The Family Welfare Movement (PKK) at RT 03 RW 02 Sumbersekar Dau, the following facts are found: 


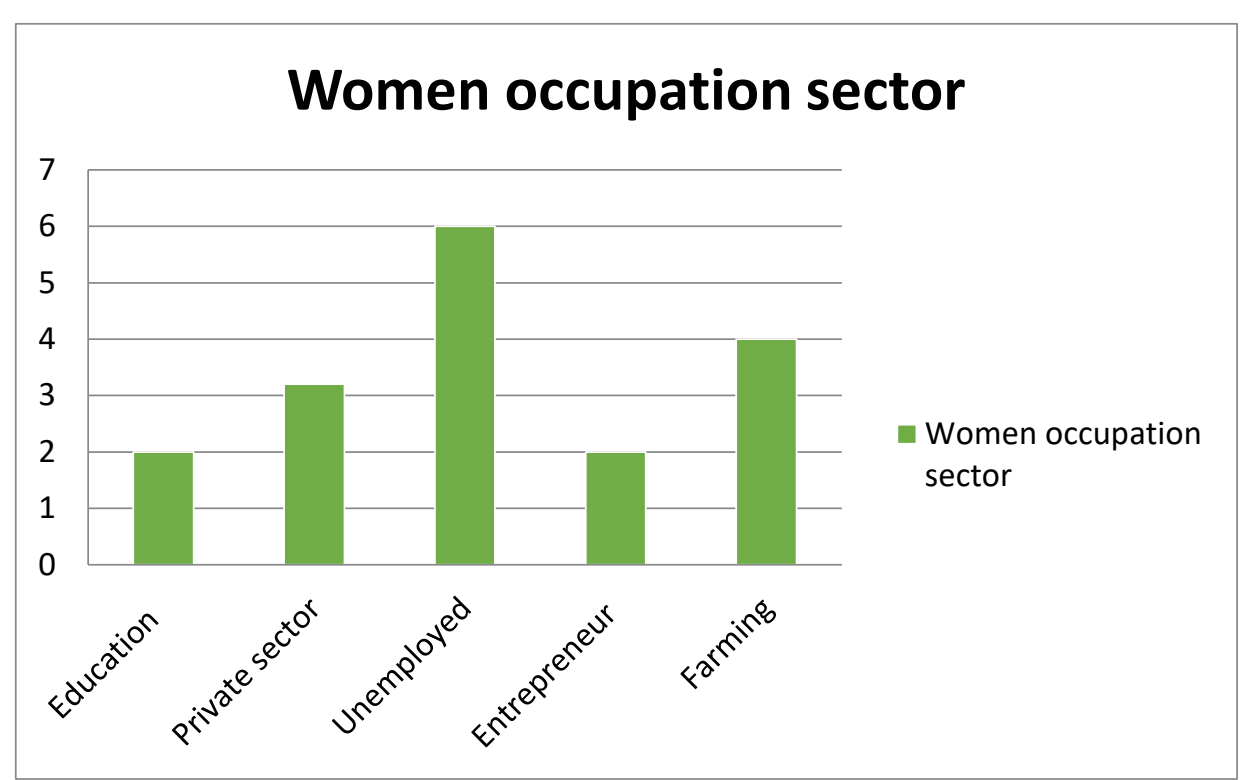

Chart 1. Women occupation sector in RT 03 RW 02 Sumbersekar, Dau Malang

The present community service provides training on patchwork. The reason why patchwork is selected because the patchwork is not only able to give space for the participants to be creative, but it also offers a chance for the participants to get income by selling their patchwork products. Moreover, patchwork which is made from leftover fabrics is seen as a way of recycling program. It is because those left over fabric can be value-added by transforming them into patchwork blanket, bed sheets, tablecloth, etc. T

\section{Method}

The present community was be carried out in three stages namely planning, implementation and evaluation.

\subsection{Planning}

The successfulness of a program is directed by a good plan ahead. In order to achieve the target outcome, the project team will make a careful plan by using Focused Group Discussion. It is planned that the FGD will involve stakeholders of the target institution so that they can identify the best approach to conduct the community service program. The FGD is expected to not only direct the program but also to make sure that the program suits the target demands. The Focused Group Discussion is carried out for the purpose of making sure that the program can solve the issue in the community. Furthermore, in this stage, the stakeholders and the team will collaborate and coordinate in order to plan the process of the community empowerment program.

\subsection{Implementation}

After thorough planning, the team will implement the program by having workshop in two areas. The first workshop will focus on the patchwork skill, which may take 3-4 meetings. The meetings will be carried out in order to give proper skill to the participants. Groups of participants will be created so that the participants can learn and work collaboratively for the program. In addition, the group is also intended to ease the process so that the project team can monitor each group's performances. After the first workshop on patchwork, the second workshop will focus on marketing issue. This will cover packaging, labeling and also marketing. The skill is crucial because the target institution needs to have the skill to distribute or sell the product to larger customer. In this case, online marketing is planned to be introduced so that they can 
Website : http://ejournal.umm.ac.id/index.php/jpa | E-mail : jpa@umm.ac.id

Jurnal Perempuan dan Anak (JPA), Vol 3 No.2, Agustus 2020, pp. 65-73

ISSN: 2442-2614 print | 2716-3253 online

Universitas Muhammadiyah Malang

manage their own product. Additionally, the marketing skill is also expected to achieve the sustainability of the program.

\subsection{Evaluation}

In order to know the results of a program, evaluation is important to be conducted. In this regard, the evaluation will be carried out by distributing survey to the participants about this community service program. The survey will highlights whether the participants get benefit as it is expected by the project member.

The following is the chart of the community service program implementation:

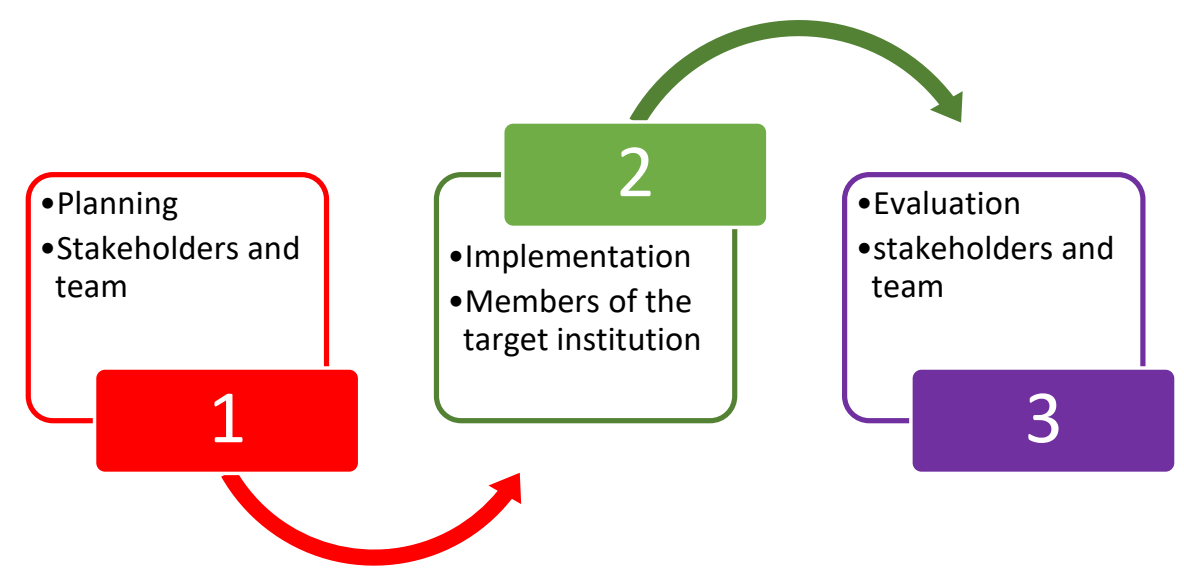

Chart 2. Program Implementation

\section{Result and Discussions}

It is a great challenge for the program organiser to implement the community service in the COVID 19 pandemic. As we have set the schedule, it is previously expected that the team can strictly follow the time frame. However, as the pandemic hit the people badly starting on March 2020, it was really hard to conduct the community service program as people are asked to be remaining at home for quite a long period. In addition, the social distancing measure is also applied which restricted people's interaction in daily basis. One more important concern that burdens the organiser was the fact that one suspected patient of COVID 19 was identified in the neighbourhood which put even more restrain in the implementation of the community service program as previously scheduled. Accordingly, the program organizer needs to carefully plan the time for the community service program to make sure that everyone's safety issues.

As the program is conducted in pandemic situation, some adjustments are significantly done with the approval of the local authority (Ibu Ketua PKK di RT 03). Based on the discussion, adjustments were made in the following points. Firstly, the adjustment was made in terms of the schedule. Based on the plan, it is expected that the program was implemented in May/ June. However, due to the COVID 19 pandemic, the team needed to delay the implementation into the second week of October. It was decided based on careful discussion with all parties involved, such as the team, participants, the local authority and also the trainer. Secondly, it was expected that the program is participated by all the members of PKK in RT 03 RW 02. However, the team decided to limit the participants into 10 people involved in this empowerment program. The 5 people who attended the workshop then transferred the skill and knowledge to the other 5 participants so that they worked collaboratively to complete the patchwork design. It was conducted to limit the number of physical interaction among the people. Next, the adjustment was also conducted in terms of the training given. As the trainer also pay a lot of concern on social distancing, the patchwork training was conducted 
Website : http://ejournal.umm.ac.id/index.php/jpa | E-mail : jpa@umm.ac.id

Jurnal Perempuan dan Anak (JPA), Vol 3 No.2, Agustus 2020, pp. 65-73

ISSN: 2442-2614 print | 2716-3253 online

Universitas Muhammadiyah Malang

both in offline and online modes. The adjustment was initiated because the training processes took more than 1 meeting to accomplish. Two meetings designed to simulate the process of patch working as well as to monitor the participants' skill in doing the patchwork.

The summary of such adjustment can be observed from the following graph:

\section{Adjustments due to COVID 19}

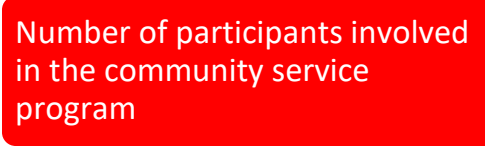

10 participants, in turn

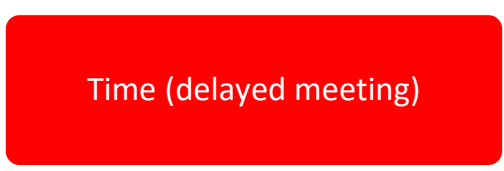

October 2020

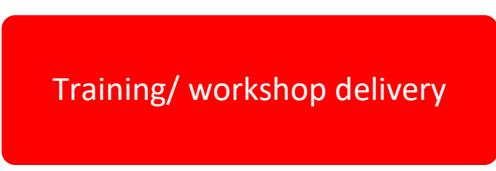

Online and offline modes

Chart 3. Program Adjustment due to COVID 19

Initial plan was introduced in the last PKK meeting in the neighbourhood before the pandemic. The following picture showed the meeting which was taken before the pandemic:
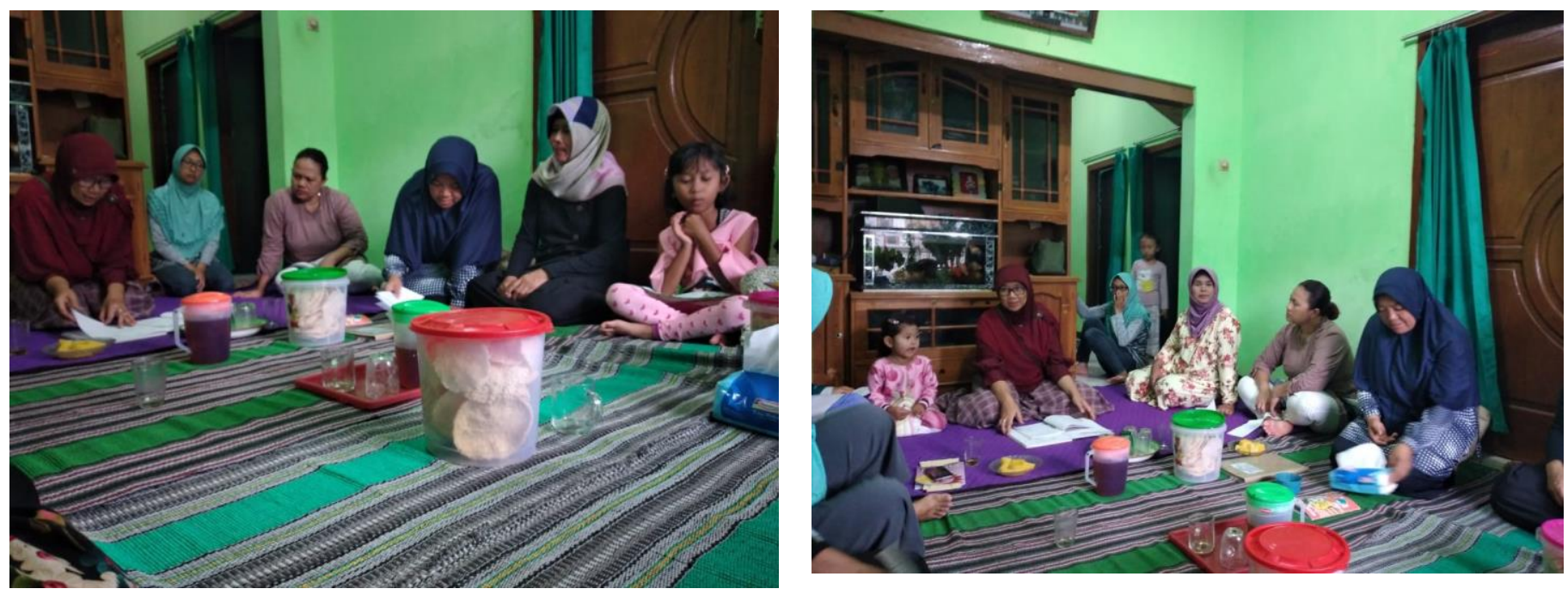

After careful considerations, the team decided to conduct the workshop on November 2020 with 12 participants who voluntarily sign up for this empowerment program. The limited number of participants is selected due to the adjustment to the COVID 19 pandemic situation which requires people to limit the number of interaction in public.

\subsection{Workshop I}

The first workshop intended to introduce patchwork to the participants. Based on the casual interview conducted during the event, most of the participants have heard about patchwork, but not really sure how to do it. Therefore, they were excited with the training as they learn about something new. They were firstly 
exposed with various products which can be made using patchwork technique. Then, the workshop continued with the stages of creating patchwork which consists of the following steps:

1. Designing the patchwork

2. Choosing the pattern

3. Gathering the materials

4. Cutting the fabrics into square, triangles, or any preferred shapes

5. Sewing the patchwork

6. Binding the patchwork pieces

7. Adding layer for the back

8. Sewing all the way around the patchwork

The pictures of the workshop can be observed in the following images:
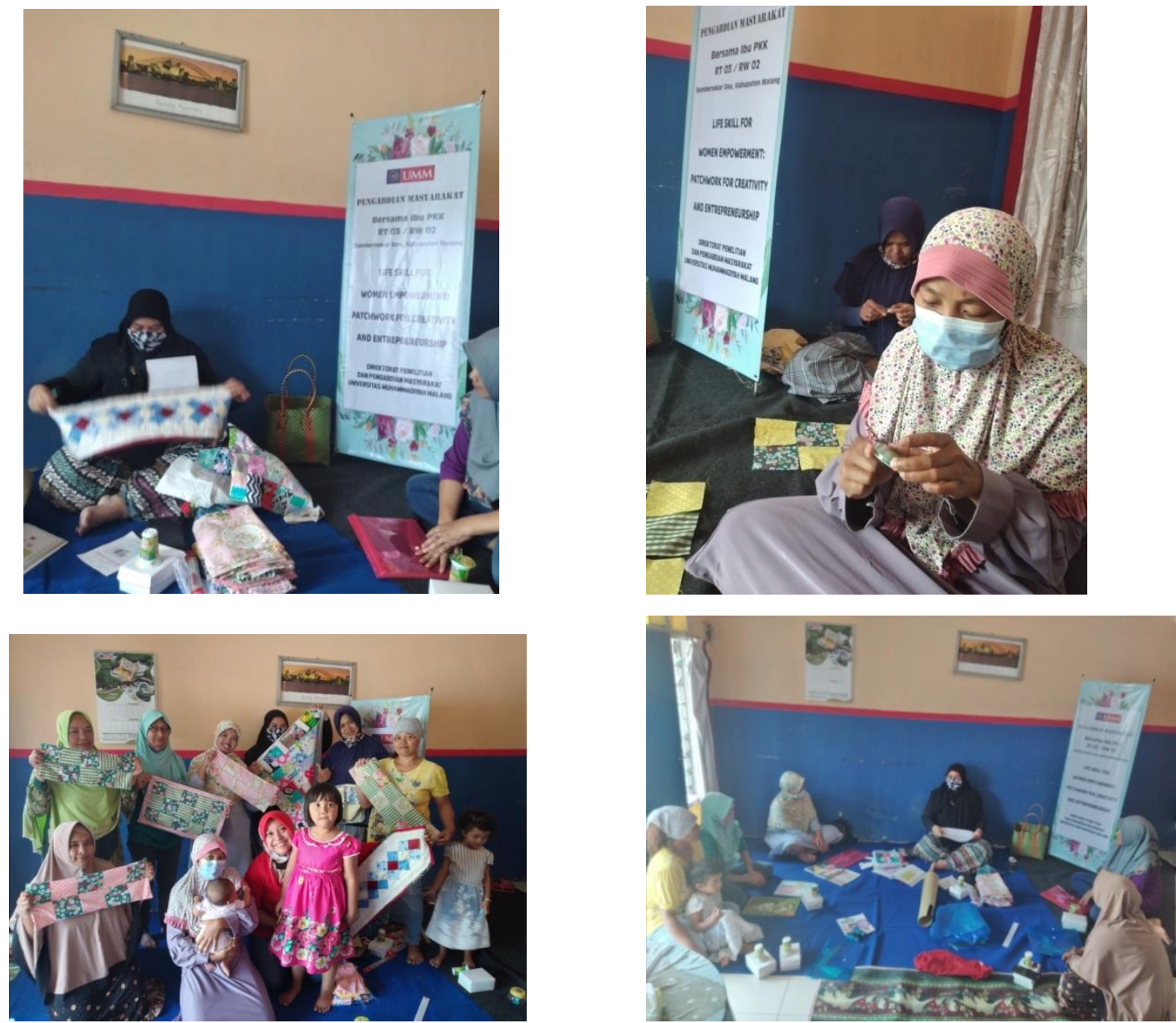

\subsection{Workshop II}

The second workshop was conducted in order to discuss the difficulties that the participants have in finishing the patchwork. The participants shared their experiences in doing the patchwork at home with the other participants and shared possible solutions to the difficulties. In addition, the participants also 
Website : http://ejournal.umm.ac.id/index.php/ipa |E-mail : jpa@umm.ac.id

Jurnal Perempuan dan Anak (JPA), Vol 3 No.2, Agustus 2020, pp. 65-73

ISSN: 2442-2614 print | 2716-3253 online

Universitas Muhammadiyah Malang

displayed their products so that they could see each others' work. It was great because they are able to see different ways of finishing the patchwork.

In the second workshop, the participants also learned to create face mask which becomes a required item in daily basis. The participants were happy and enthusiastic with the program as they thought that it is not only improving their skills, but they can create something that beneficial in this pandemic situation. The trainer also motivated them to expand the skill to be business ideas they can create.

The pictures of the second workshop can be observed in the following:
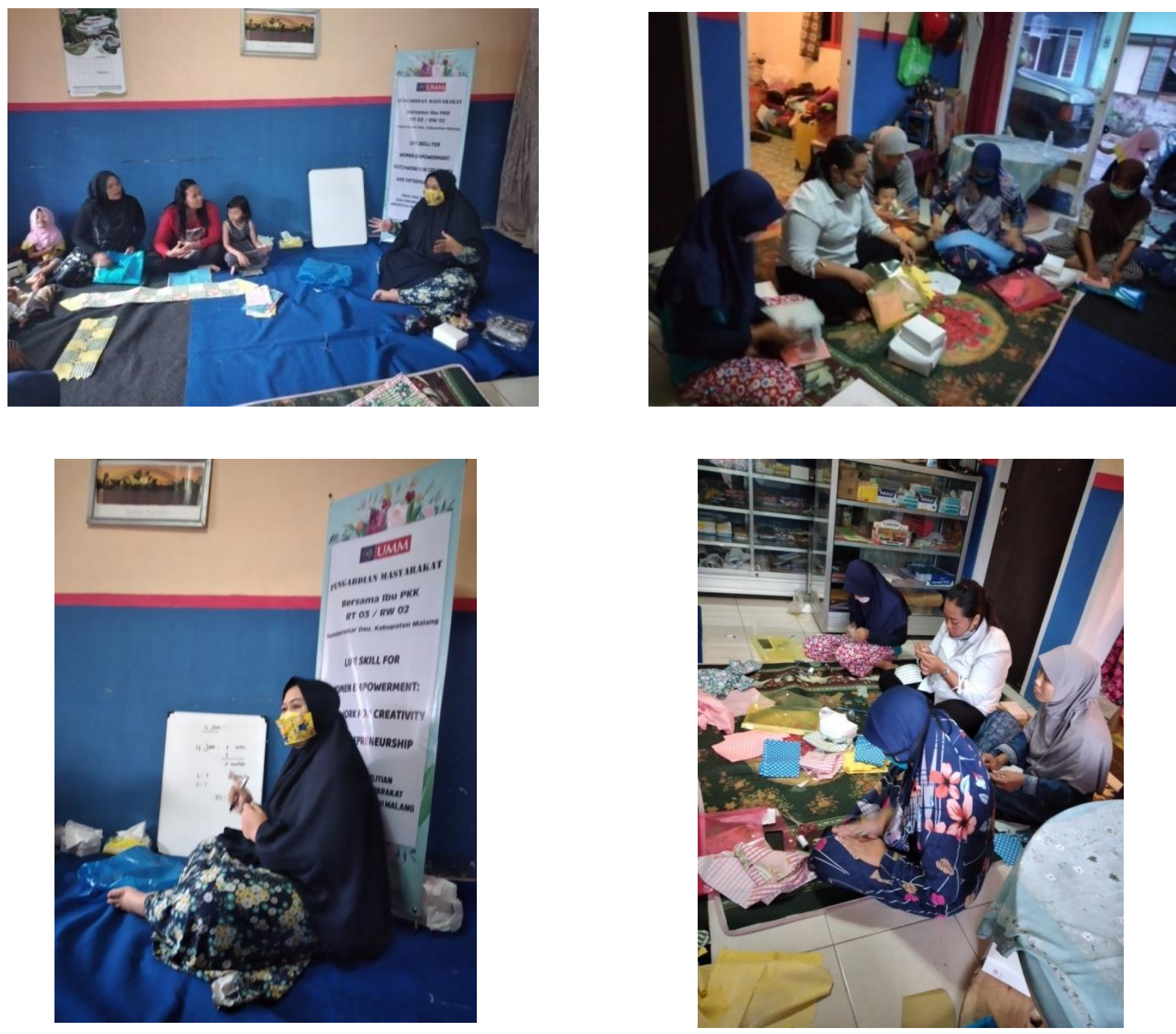

The present community service aims at providing life skill program on women empowerment. The program which was joined by housewives in the RT 03 RW 02 Sumbersekar, Dau Kab Malang was successfully conducted in the pandemic situation. The life skill which is addressed consists of the skill to have individual as well as social competence, but also the vocational skills. Similarly, Nurdin (2016) also 
Website : http://ejournal.umm.ac.id/index.php/jpa | E-mail : jpa@umm.ac.id

Jurnal Perempuan dan Anak (JPA), Vol 3 No.2, Agustus 2020, pp. 65-73

ISSN: 2442-2614 print |2716-3253 online

Universitas Muhammadiyah Malang

argued that the vocational skill as part part of life skills can be obtained by improving personal's skills in work related competence such as technical skills, cooking skills, or sewing skill.

Some adjustments in this community service were made in terms of the schedule, the number of participants of the program, and the workshop's delivery. Those adjustments are inevitable in this uncertain time. Some previous studies have mentioned that community empowerment programs have been adapted in the New Normal (S, 2020). In times of COVID 19, people's engagements are transformed, as they may even prefer to restrict their social life, and prefer more on online or digital form (Fisher et al., 2020). Due to this, all of the participants were required to wear face mask and obey the health protocol. It was interesting to note that although the number of participants are restricted, the participants attended the sessions along with their kids. This happened because the participants are housewives who are mainly responsible for the children at home. When they had to attend some occasions, sometimes they had no other option than bringing their children along to keep them safe and sound. One of the participants even brought her babies, and still could manage herself in the workshop. Moreover, the program also fosters the participants' collaboration skills because they worked in pair to make sure that they were on the right track in a supportive way. It was also mentioned in the work of Fatah (2020) who labeled this as collaborating dimension of community empowerment program which provides the participants to work with their peers.

In the nutshell, community empowerment program is the process to create community with better control over its environment, which is carried for development (Saleh \& Mujahiddin, 2020). Expectedly, the community service program will develop the participants' life skills, particularly the skill to survive in this COVID 19 pandemic using the skills and knowledge they have gained in the process. By obtaining skills to do patchwork, the women can use their creativity in making households they need in their daily life. They can even do the activity while doing their domestic responsibilities at home (Susiatik \& Widiastuti, 2020). In addition, they can also expand it to use it as product that they can sell to others. The same ideas can also be applied for the skills they have obtained to create face mask which becomes a vital item in this pandemic. The entrepreneurship is also another benefit of this community service program, because the participants have the initiative to use the skills for business ideas. The same notion is identified by Rini and Rahmah (2019) who stated that the entrepreneurship in the patchwork skills can be explored not only individually but also socially. Although the topic of the program is similar to the work conducted by Evelina et al. (2017) in the way that both programs addressed the use of the leftover fabrics, the results of the present result indicated that the products are completely different. Table cloth and face mask are created in this program, which can be created and used by the participants for everyday purpose.

\section{Conclusions}

The community service has been successfully conducted with supports of various factors, ranged from the local authorities, university as well as the trainers and participants of the program. Although it is challenging to do, the program can be adjusted in order to ensure not only the safety, but also the sustainability of the program. The life skill program particularly addressed for women to alleviate their skills and knowledge to survive in this pandemic of COVID 19.

\section{Acknowledgments}

We would like to express our sincere gratitude to the Directorate of Research and Community Services, University of Muhammadiyah Malang which provides supports to conduct this community empowerment program. We would also thank to the member of PKK organization in RT 03 RW 02 Sumbersekar, Dau, Malang and other agencies for the engagement and participation to the program. 


\section{DAFTAR PUSTAKA}

Adzmy, M. F., \& Disyacitta, F. (2018). The Indonesian Family Welfare Guidance Programme (PKK) and the Revitalisation of Corporatist state organisations: A Case Study of the Mobilisation of Support for Dewanti Rumpoko in the 2017 Batu Municipal Election. PCD Journal, 6(1), 1. https://doi.org/10.22146/pcd.31291

Evelina, T. Y., Wijayanti, R. F., \& Budiarti, L. (2017). Pelatihan Craft Kain Perca Bagi Pemberdayaan Dan. 31-38.

Fatah, M. (2020). Empowerment of Women Through Organisasi Pemberdayaan Kesejahteraan Keluarga (Family Welfare and Empowerment Organization) in The Family Income Development Program in Banjarbaru City, Indonesia. European Journal of Political Science Studies, 3(2), 96-111. https://doi.org/10.46827/ejpss.v3i2.838

Fisher, J., Languilaire, J. C., Lawthom, R., Nieuwenhuis, R., Petts, R. J., Runswick-Cole, K., \& Yerkes, M. A. (2020). Community, work, and family in times of COVID-19. Community, Work and Family, 23(3), 247-252. https://doi.org/10.1080/13668803.2020.1756568

Masyhud, Nurbatra, L. H., Hartono, \& Dwi Anggraini Puspita. (2019). Life Skill Education (LSE) in nonformal education setting. EDUCAFL: Education of English as a Foreign Language, 2(1).

Nurdin, A. (2016). Pendidikan Life Skill Dalam Menumbuhkan Nonformal Paket C. Tarbawi, 2(2), 109118.

Rini, E. I. H. A. N., \& Yuliani Rahmah. (2019). Patchwork sebagai sarana bina kreatifitas di panti asuhan semarang. "HARMON, 3(1).

S, C. K. N. (2020). Alternative Community Empowerment Programin the New Normal Time. 29-36.

Saleh, A., \& Mujahiddin, M. (2020). Challenges and Opportunities for Community Empowerment Practices in Indonesia during the Covid-19 Pandemic through Strengthening the Role of Higher Education. Budapest International Research and Critics Institute (BIRCI-Journal): Humanities and Social Sciences, 3(2), 1105-1113. https://doi.org/10.33258/birci.v3i2.946

Susiatik, T., \& Widiastuti, E. H. (2020). Empowering women in developing autonomous enterprises to enhance family welfare in Bendan Duwur sub-district Gajahmungkur district. South East Asia Journal of Contemporary Business, Economics and Law, 21(5), 195-200. 